\title{
'Committed, motivated and joyful?' Job satisfaction and organisational commitment of managers at a South African public utility
}

\author{
Authors: \\ Claude-Hélène Mayer ${ }^{1}$ \\ Lynette Louw ${ }^{1}$ \\ Jeremy Baxter ${ }^{2}$ \\ Affiliations: \\ ${ }^{1}$ Department of \\ Management, Rhodes \\ University, South Africa \\ ${ }^{2}$ Department of Statistics, \\ Rhodes University, \\ South Africa \\ Correspondence to: \\ Lynette Louw \\ Email: \\ I.louw@ru.ac.za \\ Postal address: \\ PO Box 94, Grahamstown \\ 6140 , South Africa \\ Dates: \\ Received: 13 Oct. 2014 \\ Accepted: 23 Mar. 2015 \\ Published: 04 Aug. 2015 \\ How to cite this article: \\ Mayer, C., Louw, L. \& \\ Baxter, J., 2015, "'Committed, \\ motivated and joyful?" \\ Job satisfaction and \\ organisational commitment \\ of managers at a South \\ African public utility', Acta \\ Commercii 15(1), Art. \#291, \\ 12 pages. http://dx.doi. \\ org/10.4102/ac.v15i1.291
}

\section{Copyright:}

(C) 2015. The Authors.

Licensee: AOSIS

OpenJournals. This work is

licensed under the Creative

Commons Attribution

License.
Objective: This study focuses on an assessment of managerial job satisfaction and commitment in the context of a vibrant and rapidly changing public utility from a positive organisational behaviour (POB) perspective. It aims at contributing towards an in-depth understanding of positive micro-organisational behaviour.

Problem investigated: The aim of this study was to gain deeper insights into the relationship between job satisfaction (JS) and organisational commitment (OC) in terms of the how and why' at a selected public utility in the Eastern Cape Province.

Design: This single case study uses a mixed-method approach within the pragmatism research paradigm.

Findings: Findings show that managers across cultures share a positive organisational psychology approach on JS and OC. The JS of managers is mainly influenced by their satisfaction with working with colleagues and supervisors, and with strategies of motivation, as well as their dissatisfaction with the use of power, pay and promotion. OC was mainly influenced by positive collegial relationships, the organisation's positive influence on the environment and on others, the enabling work environment and the location of the organisation.

Originality/value: The article introduces new ideas in positive organisational behaviour research and reconstructs the image of South African organisational behaviour based on qualitative and quantitative data.

Conclusion: This article shows that post-modern African organisations are opening new frontiers to building positive-oriented organisational cultures whilst creating constructive and future-orientated mindsets, which may spill over into society.

\section{Introduction and theoretical background}

During the past decade, publications and conferences on management in African organisations (Kamoche 2011a; 2011b) and in global contexts (Mangaliso 2001; Jackson 2004) ${ }^{1}$ have increased steadily. In various African contexts and organisations, job satisfaction (JS) (Walumbwa et al. 2005) and organisational commitment (OC) (Gbadamosi 2003; Wasti 2003; Nyengane 2007; Pillay 2008) have been researched. Most of the previous research is quantitative in nature. Although quantititative research provides insights into the relationships between variables, it does not necessarily provide in-depth meaningful conclusions on micro-psychological levels (e.g. Sempane, Rieger \& Roodt 2002; Buitendach \& De Witte 2005).

In research on and from Africa, scholars have been arguing that in post-apartheid South Africa, managers should adopt a positive approach in organisations (Roberts 2006; Du Plessis \& Barkhuizen 2011) to lead towards a positive organisational culture and paradigm. At the same time, it has been highlighted that there is a need for context-specific research and theories within the African management context (Zoogah 2008).

\section{The context of positive organisational behaviour in South African management}

In the past, management research in Africa has focused on challenging topics, such as shortages of managerial knowledge, skill and pervasive talents, and the inability to organise production and run operations effectively (Edoho 2001) together with ethnicity and discrimination that need to be tackled in the African human resources (HR) management context (Kamoche 1.For example, LMSSSA Conference, Cape Town, 2010; IACCP Conference, Stellenbosch, 2012; ICP Conference, Cape Town, 2012 ; AOM
Africa Conference, Johannesburg, 2013, African research group International cofnerence on management in Africa, Nottingham, 2013 ; AOM Africa conference, Garborone, 2014. 
2011a; 2011b). Jackson (2002:998) maintains that managing people in Africa is framed with a pejorative 'developing/ developed' world paradigm, which is bound to a negative view of African management and an assumed need to develop managers in Africa from a Western point of view. Articles stress that pre-colonial knowledge, local resources and indigenous knowledge systems need to be reactivated, and recommendations are provided (Kiggundu 1991; Jacob 2005; Jackson, Louw \& Zhao 2013). The literature on management in Africa often leaves the reader with broad or stereotypic concepts of Africa or sub-Saharan Africa (e.g. Kiggundu 1991). At the same time, it attempts to construct new culture-based African management theories, which are based on regional or continental generalisations (Fashoyin 2005; Inyang 2008). However, the literature hardly ever presents context-specific and micro-psychological insights into selected African (organisational) contexts that provide scientists and practitioners with differentiated and positive information. Du Plessis and Barkhuizen (2011) argue that in public and private organisations in South Africa, the HR manager is seen as being the person responsible for the employees' well-being. A general positive paradigm is needed in organisations (Du Plessis \& Barkhuizen 2012; Mayer \& Van Zyl 2013) and managers need to take an active part in creating a positive perspective (Luthans 2002a; Mayer 2011).

The positive organisational behaviour (POB) research integrates the understanding of positive cognitions, affects and behaviours in organisational settings (Van Zyl \& Stander 2013). Luthans (2002b:59) defines POB as 'the study and application of positively oriented human resource strength and psychological capacities that can be measured, developed, and effectively managed for performance improvement' in the workplace. Encouraging POB has a strong effect on individual and group-related behaviours in organisations (Lyubomirsky 2013) and in African organisational contexts (Mayer \& Van Zyl 2013). Recent studies show that organisations must turn their focus from problems and the question of 'what went wrong' to research on POB and the question of 'what went right' (Luthans 2002a) to focus on positively redefining and reconceptualising African organisations and management (Mayer 2008).

POB concepts include JS and OC, inter alia, that can promote health and well-being in organisations (Begley \& Czajka 1993; Du Plessis \& Barkhuizen 2012). Particularly in South Africa, there has been an interest in studying well-being (Van der Merwe 2005), as well as JS (Louw, Mayer \& Baxter 2012) and OC (Pillay 2008; Mayer, Louw \& Louw 2010; Mayer 2011).

\section{Job satisfaction}

JS has been widely studied (Huang \& Hsiao 2007). As Gruneberg (1979) points out:

Most individuals spend a large part of their working lives at work, so that an understanding of factors involved in job satisfaction is relevant to improving their well being and hence is an important aspect of their lives. (p. 1)
This sentiment is also supported by Rahman and Iqbal (2013:17) who indicate that 'it is essential for management to know the satisfaction factors of their employees'. The popularity of studying JS can also be attributed to the relevance of this field of study to the physical and mental well-being of employees (Strümpfer \& De Bruin 2009). JS is strongly connected to well-being in the organisation (Strümpfer \& De Bruin 2009), influences the mobilisation of resources and is viewed as a POB-related concept (Youssef \& Luthans 2007).

JS is defined as a pleasurable or positive emotional state resulting from the appraisal of one's job and job experience (Alessandri et al. 2012). 'Job satisfaction is a combination of both what an employee feels (affect) about his/her job and what he/she thinks (cognition) about the various aspects of his/her job' (Rayton \& Yalabik 2014:2386). For many years the dominant view of JS was situational, with interventions aimed at increasing satisfaction by improving job characteristics (Houghton \& Jinkerson 2007:45). Job characteristics such as pay, work, opportunity for promotion, supervision and co-workers, illustrate the multidimensional aspects of the subject. JS is also related to personality traits (Judge et al. 1999) and organisational citizenship behaviour (Illies, Scott \& Judge 2006), and is a particularly relevant outcome to assess in positivity research (Youssef \& Luthans 2007:774).

In a context-specific situation (e.g. Brief 2003; Kilduff 2006; Corley \& Gioia 2011), a POB approach is needed when researching JS in organisations (Louw et al. 2012). Previous research in South Africa has found that significant positive relationships exist between all the motivational factors and JS, as well as with commitment (Krüger \& Rootman 2010). 'In order to create a working environment that encourages people to stay with their respective organisations, managers need to review existing pay practices so as to offer fair pay, provide challenging and meaningful work tasks, and foster positive co-worker relationships' (Lumley et al. 2011:115).

\section{Organisational commitment}

OC is defined as the 'relative strength of an individual's identification with and involvement in a particular organisation' (Allen \& Meyer 1990:1). It is viewed as a psychological connection that individuals have with their organisation, characterised by the strong identification with their organisation (Lumley et al. 2011:105). Mowday, Steers and Porter's (1979:225-226) seminal definition of OC deals with three factors:

- a strong belief in and acceptance of the organisation's goals and values

- a willingness to exert considerable effort on behalf of the organisation

- a strong desire to maintain membership in the organisation.

Recent research in South Africa has shown that OC moderates the effect of occupational stress in organisations (Coetzee \& Rothmann, 2005). Committed employees can deal with 
stress better than non-committed employees (Siu 2002). OC provides people with stability and feelings of belonging, and thereby contributes to reduced stress and increased health and well-being in organisations (Siu 2002). Hence, a committed workforce is an added advantage to an organisation. OC also forms part of an organisation's competitive advantage: committed employees remain with the organisation through 'thick and thin', attend work regularly, work for a full day (and perhaps more), protect organisational assets and share common goals (Allen \& Meyer 1990) As Jung and Ritz (2014) points out:

Highly committed employees take ownership of their job and do not simply do the job, but own it and do it the best it can be done. They are dedicated to the organization's goals, are highly engaged in performing their tasks, and speak positively about their organization, both on the inside and outside, because they care about the employer's reputation. (p. 465)

Lok and Crawford (2004:324) have suggested that the success of an organisation depends on the level of involvement and commitment of employees. There are different typologies of OC (Becker 1960; Kanter 1968; Mowday et al. 1979). For the purpose of this study, the typology of Allen and Meyer (1990) is used because it is a reliable and valid research instrument that has been widely applied. There are three OC profiles, namely affective, normative and continuance profiles (Meyer et al. 2002). Although each commitment profile represents a relationship between organisation and employee, the relationships differ from each other in nature. Whilst there are differences in nature between these commitment profiles, the multidimensional nature of each profile also 'integrates attitudinal and behavioural approaches' (Van Dyk \& Coetzee 2012:3).

Employees with strong affective commitment will stay because they want to do so (Allen \& Meyer 1990:3) - relationship between the employees and their co-workers and supervisor. Employees with strong continuance commitment feel they have to stay - the individual's association with the organisation is based on assessment of economic benefits gained (Beck \& Wilson 2000:115). Employees with strong normative commitment feel obligated to stay - to repay the benefits from the organisation by remaining as part of the workforce (Allen \& Meyer 1990:9).

OC is affected by factors such as autonomy at work, type and variety of work, level of responsibility, quality of social relationships, rewards, remuneration, opportunities for promotion, and career options (Riggio 2009). OC captures the cognitive, affective, social and higher order dimensions and is emphasised in POB research (Luthans, Youssef \& Aviolio 2007).

\section{The interrelationship of job satisfaction and organisational commitment}

Strong positive relationships have been found between JS and OC (Kotze \& Roodt 2005; Lumley et al. 2011). Furthermore, JS and OC are positively related to performance (Wright \&
Bonett 2002) and are negatively related to absenteeism, tardiness and turnover (Harrison, Newman \& Roth 2006). Satisfied employees are committed to the organisation, and committed employees attend work, stay with the organisation, perform well and engage in $\mathrm{POB}$ (Aamodt 2007). It is, however, highlighted by Meyer et al. (2002) that whilst research strongly supports JS and OC being correlated, the causal ordering of these variables is contested. South African research suggests that there is a significant positive relationship between JS and affective and normative commitment variables (Mathieu \& Zajac 1990; Lumley et al. 2011). Spector (2008) confirms that JS relates most strongly to affective commitment, which is confirmed by the meta-analyses conducted by Meyer et al. (2002) and Mathieu and Zajac (1990).

\section{Purpose and objectives}

The aim of this article is to show contributions of African contexts to the POB discipline by assessing JS and OC from emic and etic perspectives in a vibrant and rapidly changing public utility in the Eastern Cape of South Africa.

The contribution of this article is based on a POB perspective and contributes to previously published articles on POB in specific African contexts. Furthermore, this article fills the void of mixed-method (quantitative and qualitative) studies on JS and OC and their interrelationships, and thereby produces in-depth context-specific findings.

In achieving the aim, the intention of this study is to gain a deeper understanding of the micro-psychological insights and the relationships between JS and OC in terms of the 'how and why' (Colquitt \& Zapata-Phelan 2007) of the relationship between JS and OC among managers in a selected public utility organisation. Even though this relationship has previously been researched (e.g. Kotze \& Roodt 2005), the nature of the relationship is still unclear (Huang \& Hsiao 2007). To give effect to the research aim, the following quantitative and qualitative objectives of this study are:

- to determine the profiles of JS and OC among managers in the selected organisation

- to establish the nature of the relationship between JS and OC from an etic perspective among managers in the selected organisation

- to gain deeper knowledge of the concepts of JS and OC from the emic perspective of the managers.

To achieve the objectives of this study, the following hypotheses have been stated:

- $\quad \mathbf{H}_{\mathrm{a} 1}$ : There are statistically significant linear relationships between the scales of the JS instrument $\mathrm{H}_{\mathrm{a} 1.1}$ and the scales of the organisational commitment (OC) instrument $\mathrm{H}_{\mathrm{a} 1.2}$.

- $\mathbf{H}_{\mathrm{a} 2}$ : There is a statistically significant linear relationship between JS and OC.

\section{Research methodology}

This single case study uses a pragmatism research paradigm (Tashakkori \& Teddlie 1998:23), following an exploratory 
approach. In the mixed-methods approach (Tashakkori \& Teddlie 1998:42; Creswell \& Plano Clark, 2007), triangulation is followed and the interpretative paradigm (Collis \& Hussey 2003) is regarded as being equally important to the positivistic paradigm. In terms of the quantitative approach, explanation 'consists of establishing causal relationships between the variables by establishing causal laws and linking them to deductive or integrated theory' (Collis \& Hussey 2003:53). With regard to the qualitative approach, interpretative hermeneutics (Berger \& Luckmann 2000) and the thick description method of Geertz (1987) are used.

\section{Research setting}

The public utility used for this case study operates in the Eastern Cape Province of South Africa and is regarded as being important in its sector in the country. It is a growing organisation with numerous work sites throughout the province. The selection of this organisation was based on:

- national and regional business involvement and standing

- diversity of managers and workforce

- the implementation of transformation policies

- interest of the HR Department, the leaders and managers of the utility in the research topic

- access to the utility.

\section{Population and sampling}

A total of 29 respondents completed questionnaires from a population of 31 top and middle level managerial respondents. There were 17 managers that agreed to participate voluntarily in in-depth interviews to provide qualitative micro-organisational data.

\section{Data collection methods}

Quantitative data on JS and OC was collected by means of a self-administered questionnaire survey. Qualitative data on JS and OC was gained from in-depth interviews, observation and document analysis. Interviews and observations were conducted by the researchers. Time for observations in the organisation was provided by the HR department. Written notes were taken of the observations.

The interviews included questions such as: 'How do you feel working in this organisation?', 'Could you please describe how satisfied you are working in the organisation?', 'What makes you feel committed?', 'Which aspects impact on your JS and on your OC?' and 'How do JS and OC impact on your health and well being?'.

The managers' in-depth interviews were recorded in full to ensure precise transcription, verbatim.

\section{Quantitative data collection research instruments}

The data on JS was collected by making use of Smith, Kendall and Hulin's (1969) Job Descriptive Index (JDI).
The JDI comprises five work facets of JS, namely: Work (18 items), Pay (9 items), Supervision (18 items), Co-workers (18 items) and Promotion opportunities (9 items). The 72 items consisted of short words or phrases. Respondents had to respond by placing a ' $Y^{\prime}$ (yes) beside an item if it described the particular aspect of the job, an 'N' (no) if it did not, and a '?' (not sure or not applicable) if they could not decide. Scoring of JS followed the instructions by Smith et al. (1969). For positive statements 'Yes' $=3,{ }^{\prime} \mathrm{No}^{\prime}=0$ and 'Not sure $^{\prime}=1$. The scores were reversed, namely 'Yes' $=0,{ }^{\prime} \mathrm{No}^{\prime}=3$ and 'Not sure' $=1$, for the negative statements.

Research conducted by Kinicki et al. (2002:25-26) stated that the JDI instrument had shown internal consistency and reliability estimates that were moderately high, whilst Fisher (1998:16) and Kass, Vodanovich and Callender (2001:321-322) confirmed the internal consistency of the five JDI scales with Cronbach alpha coefficients for each scale of 0.82 and above. As a rule of thumb, Cronbach alpha coefficients between 0.60 and 0.70 are regarded as moderate, between 0.70 and 0.80 as good and above 0.80 as being very good to excellent (Hair et al. 2007:244). Even though the generally accepted threshold for Cronbach alpha is 0.70 , this limit may be lowered to 0.60 in exploratory research (Nunnally 1978; Robinson, Shaver \& Wrightsman 1991). According to Pennington and Riley (1991:22), this instrument is well documented as being valid and reliable, highly regarded, easy to complete and the most used research instrument in job satisfaction-related research. This is confirmed by Kinicki et al. (2002:15), who stated that JDI had been used in 210 studies.

Allen and Meyer's (1990) research instrument (organisational commitment questionnaire - OCQ), was used in this study to collect data on OC. The OCQ instrument had been previously tested for reliability in a variety of cultural contexts, industries and international contexts (Meyer \& Allen 1991; Clugston, Howell \& Dorfman 2000; Lee et al. 2001; Rashid, Sambasivan \& Johari 2003; Wasti 2003). As can be seen in Table 1, good reliability values (Cronbach alpha coefficients) for each dimension had been previously found.

With regard to the validity of the questionnaire, Allen and Meyer (1990:6) subjected the 21 items comprising the three OC scales to a factor analysis. Clugston et al. (2000:13) found that there was validity in the Allen and Meyer (1990) measuring instrument. Wasti (2003:307) also performed a factor analysis with regard to the questionnaire in a Turkish context, which yielded a three-factor solution, supporting the validity of the instrument. This instrument is valid and reliable in the South African context (Manetje 2005;

TABLE 1: The reliability of the Allen and Meyer (1990) OCQ questionnaire.

\begin{tabular}{lcccc}
\hline $\begin{array}{l}\text { Commitment } \\
\text { dimension }\end{array}$ & $\begin{array}{c}\text { Allen and } \\
\text { Meyer (1990) }\end{array}$ & $\begin{array}{c}\text { Clugston } \\
\text { et al. (2000) }\end{array}$ & $\begin{array}{c}\text { Lee } \text { et al. } \\
\text { (2001) }\end{array}$ & $\begin{array}{c}\text { Rashid } \\
\text { et al. (2003) }\end{array}$ \\
\hline Affective & 0.87 & 0.85 & 0.86 & 0.92 \\
Continuance & 0.75 & 0.88 & 0.61 & 0.93 \\
Normative & 0.79 & 0.80 & 0.74 & 0.72 \\
\hline
\end{tabular}

Source: Allen, N.J. \& Meyer, J.P., 1990, 'The measurement and antecedents of affective, continuance and normative commitment to the organization', Journal of Occupational Psychology (63), 1-18

OCQ, organisational commitment questionnaire. 
Louw \& Boshoff 2006; Nyengane 2007; Van StuyvesantMeijen 2007; Pittorini 2008).

\section{Quantitative data analysis}

This data was analysed using the $R$ statistical software package (R Development Core Team 2010). Each of the research instruments considered in this study was used to calculate descriptive statistics, the mean and standard deviation (relating to JS and OC scales), and univariate statistical methodologies were used to test the hypotheses. As a result of the small size of this data set and the exploratory nature of this study, care should be taken when interpreting the results reported owing to the inflated overall Type I error (Salkind 2010:1576)

Bartlett's K-squared test for more than two independent populations was used to determine if the respective population's scales variances were significantly different across the relevant scales. A non-parametric equivalent test, the Kruskal-Wallis rank sum test, was used to assess if the median or location parameters were significantly different. Pairwise Wilcoxon rank sum tests, using Holm's method, were used to adjust the p-value for the multiple comparisons if the Kruskal-Wallis rank sum test was found to be significant. Pearson's correlation coefficient and the associated t-test were used to assess the relationship and significance of the relationship between the scales of the JS instrument, the scales of the organisational commitment instrument, and the scales of the JS and OC instruments.

All the scales in the measuring instrument were subjected to Cronbach alpha coefficient analysis for reliability. Reliability indicates whether or not an instrument's measures are free from error, therefore yielding consistent results (Collis \& Hussey 2003:58). However, because of the small number of respondents in this study, care was taken in the interpretation of the results. Validity is the extent to which the survey information is relevant to the conclusion being drawn, and is sufficiently accurate and complete to support the conclusion (Collis \& Hussey 2003). Owing to the sample size of this study, the quantitative validity of the research instruments was not determined, but a brief review of previous research pertaining to the reliability and validity has been provided.

\section{Qualitative data analysis, criteria and ethical considerations}

The qualitative data on JS and OC were analysed by content analysis and according to the five-step process of Terre Blanche, Durrheim and Kelly (2006:322-326), including:

- Step 1: Familiarisation and immersion.

- Step 2: Inducing themes.

- Step 3: Coding.

- Step 4: Elaboration.

- Step 5: Interpretation and checking of data.

Quantitative and qualitative data was integrated and interpreted.
Regarding the qualitative data, qualitative research criteria were considered, such as confirmability (Riege 2003:78; Seale 2002:105), credibility (Poggenpoel 1998:349) and transferability (Van der Riet \& Durrheim 2008:90). Relevant strategies of qualitative data collection, analysis and interpretation were used. The data collection and analysis were approved by the utility and the research institution, and complied with the principles of research ethics, such as voluntary participation and anonymity, the rights of the managers, the creation of informed consent, confidentiality and transparency (Mayer 2008).

\section{Limitations of research}

The limitation of this research stems from the fact that only one selected organisation with a limited number of respondents was included in the research sample. Moreover, respondents represented management at the selected organisation, and therefore findings should be viewed as exploratory in nature gathered by combining quantitative and qualitative insights.

\section{Research findings Biographical findings}

With regard to the biographical information, the most prevalent age group was between the ages of 40 and 49 $(36.67 \%)$ and the majority of the respondents were male (76.67\%). Middle management comprised $86.20 \%$ of the sample and top management $13.80 \%$. Seventy-six per cent of the respondents were religious, and $70 \%$ were married. Forty-five per cent of the respondents were from the African group, 38\% from the white group, 14\% from Indian and 3\% from the mixed race group.

\section{Quantitative results on job satisfaction}

There were 24 respondents' responses that were considered as usable for the JS instrument. This data was cleaned by dropping subjects who left 15 (approximately 25\%) or more items blank, resulting in the removal of six respondents. The Supervision, Co-workers, and Work scales have 18 items each, whereas the Pay and Promotion scales have 9 items each. As a result, the scores on the Pay and Promotion scales were doubled to equate the possible ranges on the five scales. The scores were then summed to obtain five scale scores, resulting in each scale having a potential range of 0 to 54 (Kantor 1991). As shown in Table 2, the scales on the JS instrument pertaining to Co-workers, Supervisors, Pay

TABLE 2: Cronbach alpha scores for JS - Smith et al. (1969) JDI.

\begin{tabular}{lcc}
\hline JDI scales & Cronbach alpha & Interpretation (Sekaran 1992) \\
\hline Co-Workers & 0.8021 & Good \\
Supervisors & 0.9116 & Good \\
Work & 0.7840 & Acceptable \\
Pay & 0.8537 & Good \\
Promotion & 0.8288 & Good \\
\hline
\end{tabular}

Source: Smith, P.C., Kendall, L.M. \& Hulin, C.L., 1969, The measurement of satisfaction in Source: Smith, P.C., Kendall, L.M. \& Hulin, C.L., 1969, The measurement of satisfoc
work andretirement: A strategy for the study of attitudes, Rand McNally, Chicago JDI, Job Descriptive Index; JS, job satisfaction. 
TABLE 3: Summary statistics, JS - Smith et al. (1969) JDI.

\begin{tabular}{lcccl}
\hline JDI scales & $\begin{array}{c}\text { Sample } \\
\text { size }\end{array}$ & Mean & $\begin{array}{c}\text { Standard } \\
\text { deviation }\end{array}$ & $\begin{array}{l}\text { Pennington and Riley } \\
\text { (1991) rating }\end{array}$ \\
\hline Co-Workers & 23 & 41.7826 & 9.3951 & Highly satisfied \\
Supervisors & 22 & 40.2727 & 13.5933 & Moderately satisfied \\
Work & 23 & 38.8695 & 7.9561 & Moderately satisfied \\
Pay & 24 & 26.7500 & 15.2294 & Moderately dissatisfied \\
Promotion & 24 & 19.1666 & 15.7139 & Moderately dissatisfied \\
\hline
\end{tabular}

Source: Smith, P.C., Kendall, L.M. \& Hulin, C.L., 1969, The measurement of satisfaction in work andretirement: $A$ strategy for the study of attitudes, Rand McNally, Chicago

JDI, Job Descriptive Index; JS, job satisfaction.

and Promotion had good Cronbach alpha values of above 0.8021, whilst work had an acceptable Cronbach alpha value of 0.7840 .

The results were compared using a scoring system for a general level of JS, developed and used by Pennington and Riley (1991:24). Given that the maximum score for each JS scale, according to the JDI, was 54, the basic level of JS was indicated by the mid-point of 27. A highly dissatisfied response was indicated by a score of 13.5 or below, whilst a moderately dissatisfied response was indicated by a score above 13.6, but at or below the mid-point of 27. Scores between 27 and 40.5 were evaluated as moderately satisfied responses, whilst those above 40.5 were assessed as highly satisfied, as shown in Table 3. The sample size, mean and standard deviation of the JDI scale scores are also shown in Table 3.

As shown in Table 3, there was generally a highly satisfied response to Co-workers and moderately satisfaction with Supervisors and Work. There was also a general feeling that the selected public utility was an organisation in which it was difficult to be promoted, as indicated by the mean score for Promotions of 19.1666. Fourteen (47\%) of the respondents indicated that there were limited promotional opportunities. The respondents were thus moderately dissatisfied with Pay and Promotion.

This data provided sufficient evidence that the JS scales had unequal population variances (Bartlett's K-squared $=14.5708, \mathrm{df}=4, p$-value $=0.0057)$. These scales have significantly different medians (Kruskal-Wallis chi-squared $=34.5403, \mathrm{df}=4, p$-value $=5.773 \mathrm{e}-07)$. Pairwise Wilcoxon rank sum tests, using Holm's method to adjust the $p$-value for the multiple comparisons, showed significant differences in the median scores between Co-Workers and Pay ( $p$-value $=0.0069)$, Co-Workers and Promotion ( $p$-value $=0.0001)$, Pay and Supervision $(p$-value $=0.0171)$, Pay and Work $(p$-value $=$ $0.0171)$, Promotion and Supervision $(p$-value $=0.0007)$, and Promotion and Work ( $p$-value $=0.0006)$.

\section{Quantitative results on organisational commitment}

After the data was cleaned for Allen and Meyer's (1990) research instrument (OCQ), either 21 or 22 reponses were used in this study. The five-point likert scores were approriately summed to obtain the three scale scores for OC. Numerical summaries of these scores are shown in Table 4.
TABLE 4: Summary statistics, OC - Allen and Meyer (1990) OCQ.

\begin{tabular}{lccc}
\hline OCQ scales & Sample size & Mean & $\begin{array}{c}\text { Standard } \\
\text { deviation }\end{array}$ \\
\hline Affective commitment & 22 & 25.5455 & 4.8768 \\
Continuance commitment & 22 & 19.8182 & 5.7705 \\
Normative commitment & 21 & 18.5714 & 5.5639 \\
\hline
\end{tabular}

Source: Allen, N.J. \& Meyer, J.P., 1990, 'The measurement and antecedents of affective, continuance and normative commitment to the organization', Journal of Occupational Psychology (63), 1-18

$\mathrm{OCQ}$, organisational commitment questionnaire; $\mathrm{OC}$, organisational commitment.

TABLE 5: Cronbach alpha scores, OC - Allen and Meyer (1990) organisation commitment research instrument (OCQ).

\begin{tabular}{lcc}
\hline $\begin{array}{l}\text { Organisational commitment } \\
\text { (OCQ scales) }\end{array}$ & $\begin{array}{c}\text { Cronbach } \\
\text { alpha }\end{array}$ & $\begin{array}{c}\text { Interpretation } \\
\text { (Sekaran 1992) }\end{array}$ \\
\hline Affective commitment & 0.7042 & Acceptable \\
Continuance commitment & 0.7541 & Acceptable \\
Normative commitment & 0.7536 & Acceptable \\
\hline
\end{tabular}

Source: Allen, N.J. \& Meyer, J.P., 1990, 'The measurement and antecedents of affective, continuance and normative commitment to the organization', Journal of Occupational Psychology (63), 1-18

OCQ, organisational commitment questionnaire; OC, organisational commitment.

The OC profile of each manager was determined by calculating the maximum score of each manager on each of the scales. The majority of respondents, 15 (71.4\%), showed a preference for affective commitment. Five $(23.8 \%)$ of the respondents had a continuance commitment, whilst one (4.8\%) respondent had a normative commitment to the utility. All OCQ scales, namely for affective (0.7042), continuance (0.7541) and normative (0.7536) commitment, had acceptable Cronbach alpha values of 0.7042 and above, as shown in Table 5.

The data on the sample size, mean and standard deviation of the OCQ scale did not provide sufficient evidence that the organisational commitment scales had significantly different population variances (Bartlett's $K$-squared $=0.6235, \mathrm{df}=2$, $p$-value $=0.7322)$. The average scores of the commitment scales were significantly different $(F=10.249, \mathrm{df}=2,62$, $p$-value $=0.00014)$. Tukey's HSD test revealed that there were significant differences between the average continuance commitment and affective commitment scores (difference $=-5.727273, p$-value $=0.0024075)$, and between the average normative commitment and affective commitment scores (difference $=-6.974026$, $p$-value $=0.002355$ ).

\section{Relationship between job satisfaction and organisational commitment}

Pearson's correlation coefficient was used to assess the linear relationship between the various scales of the JS and OC scales. Pairwise complete observations were used in calculating the Pearson's correlation coefficients and associated $p$-values shown in Tables 6, 7 and 8 .

With regard to JS, no significant linear relationships, as shown in Table 6, was found between the scales on the JDI. Hypothesis $\mathrm{H}_{\mathrm{a} 1.1}$ is thus not supported at the $5 \%$ level of significance.

With regard to OC, one significant linear relationship was found between the scales of affective (AC) and normative 
TABLE 6: Pearson's correlation coefficients and associated $p$-values for the JDI instrument.

\begin{tabular}{lcccc}
\hline Job descriptive index & Work $(p$-values $)$ & Supervision $(p$-values $)$ & Co-workers $(p$-values $)$ & Pay $(p$-values $)$ \\
\hline Work & 1 & & & \\
Supervision & $0.0815(0.7326)$ & 1 & 1 & \\
Co-workers & $0.3482(0.1324)$ & $0.0520(0.8275)$ & $0.1938(0.4129)$ & 1 \\
Pay & $0.1106(0.6425)$ & $-0.4303(0.0582)$ & $-0.0961(0.6870)$ & $-0.3526(0.1273)$ \\
Promotion & $0.1919(0.4176)$ & $-0.0271(0.9099)$ & 1 & \\
\hline
\end{tabular}

Source: Author's own construction

JDI, Job descriptive index.

TABLE 7: Pearson's correlation coefficients and associated $p$-values for the OCQ instrument.

\begin{tabular}{lccc}
\hline Correlation coefficients & AC ( $p$-values) & CC ( $p$-values) & NC \\
\hline AC & 1 & & \\
CC & $0.3001(0.1985)$ & 1 & \\
NC & $0.6350(0.0026)$ & $0.3226(0.1654)$ & 1 \\
\hline
\end{tabular}

Source: Author's own construction

$\mathrm{OCQ}$, organisational commitment questionnaire.

TABLE 8: Pearson's correlation coefficients and associated $p$-values between the $J D I$ and the OCQ instruments.

\begin{tabular}{lccc}
\hline Job descriptive index & AC $(p$-values $)$ & CC $(p$-values $)$ & NC $(p$-values $)$ \\
\hline Work & $-0.0240(0.9198)$ & $0.1385(0.5604)$ & $0.2191(0.3535)$ \\
Supervision & $0.4789(0.0326)$ & $-0.3169(0.1734)$ & $0.2734(0.2435)$ \\
Co-workers & $-0.4161(0.0680)$ & $-0.2029(0.3909)$ & $-0.1732(0.4653)$ \\
Pay & $-0.3583(0.1208)$ & $0.2436(0.3006)$ & $-0.3372(0.1460)$ \\
Promotion & $-0.0748(0.7538)$ & $-0.0984(0.6797)$ & $-0.0141(0.9531)$ \\
\hline
\end{tabular}

Source: Author's own construction

JDI, Job descriptive index; OCQ, organisational commitment questionnaire.

(NC) commitment $(r=0.635, p$-value $=0.0026)$, as shown in Table 7. Hypothesis $\mathrm{H}_{\mathrm{a} 1.2}$ is thus not supported, except between affective and normative commitment, at the $5 \%$ level of significance.

With regard to JS and OC, no significant linear relationships, as shown in Table 8, were found between the scales on the JDI and OCQ instruments, except for the significant linear relationship between supervision and affective commitment $(r=0.4789, p$-value $=0.0326)$. Hypothesis $\mathrm{H}_{\mathrm{a} 2}$ is thus not supported, except between supervision and affective commitment, at the $5 \%$ level of significance.

\section{Qualitative findings on job satisfaction}

Findings from interviewees' comments on their JS show that three aspects were particularly important:

1. satisfaction working with colleagues

2. satisfaction with strategies of motivation

3. dissatisfaction with the use of power in the organisation.

\section{Collegial support and job satisfaction}

Firstly, managers were very satisfied with working with their colleagues (P1, P3, P5, P9, P11, P12, P14, P16, P17), highlighting the friendliness and the support of colleagues with regard to work processes. Managers were very positive about the micro-relationships displayed by managers across hierarchies.

With regard to JS, managers felt that the 'collegial support' was important and extremely positive. P2 stated: 'We have got a very good team here. We work together'. The value of working together was emphasised, and a highly positive view of the colleagues and the team displayed.

\section{Motivational strategies and job satisfaction}

Secondly, managers pointed out the very positive and highly satisfying strategies to motivate managers and employees in the organisation. Interviewees differentiated the motivation strategies that they valued, such as:

- Performance management systems (P1, P3, P5, P9, P11, P12, P14, P16, P17).

- Praise and recognition within organisation (P1, P11, P12, P13, P15, P16).

- Personal career/development (P3, P4, P12, P13).

- Support (P2, P10, P13).

- Work environment/communication (P2, P6).

- Equipment (P6, P17).

- Policy framework (P6, P9).

- Meaning in work (P12).

Nine out of the 17 managers were generally satisfied with the 'performance management systems'. These managers viewed their job as mainly influenced by well-established performance management systems. However, one manager was critical of the performance management system, which he felt was only working well for senior management, but not for managers in middle management.

In addition, six managers commented on praise and recognition within the organisation - five of them emphasising the positive impact on JS, whilst one top manager, with a critical view of praise and recognition, felt he could be more valued and believed there was a lack of praise and recognition in the organisation.

For four interviewees, the personal career and development plans were extremely important with regard to JS. Four managers stated that they were very content with the personal career and development in the organisation.

Two managers mentioned that work environment and communication were important for their JS, adding that the work environment and interpersonal communication across hierarchies were positive in the organisation:

'The general atmosphere in this particular department is such that the people $[\mathrm{sic}]$ enjoy what they are doing and we try and support them as far as possible. So that they feel committed and motivated.' (P2)

P2, a top manager, pointed out that joy and enjoying work were important aspects of the institution. He stated that 
top management consciously aimed to support the staff to help them feel committed, motivated and happy in their work. This statement from a top manager showed that the organisation aimed at POB on a micro-psychological level.

Technnical equipment was important for two other managers. Both these interviewees felt that the organisation was well equipped to deal with challenges. However, two other statements showed a highly critical perspective from two middle managers with regard to the policy framework. Both felt that the organisation should increase JS by reframing policies. However, whilst they criticised the policy framework, they formulated their criticism in a positive way and suggested that the organisation should adhere to the questions and concerns that lower or middle managers might bring up (P9).

Finally, one HR manager mentioned that meaning in work (P12) contributed to her JS. This manager drew on the concept of meaningfulness as a positive micro-psychological concept:

'And I think further on, the motivation comes from the fact that people are doing meaningful work. I'm talking now about my unit, because people are doing meaningful work. And I've seen, since I've come, that people need direction. As a manager you just need to give them direction: what is it that you want, when do you want it, how do you want it, how should they do it. And they feel committed, motivated and joyful. They like their work and see meaning in it. And this is what we have to make sure that we all enjoy working here. Then it will work out.' (P12)

This HR manager gave a POB perspective, highlighting what made the work meaningful, how she led by giving the managers and employees direction and supporting them. Employees felt 'committed, motivated and joyful', which affected motivation and JS, and contributed to the meaningfulness of the work. This manager inferred that a positive organisational and personal concept of meaningfulness leads to even more positive aspects, such as OC, motivation and joy, which will contribute positively to the work in various respects.

Generally, top management and the HR manager had a positive attitude towards the organisational leadership approach and to the positive micro-level psychological aspects of the organisation.

\section{Power and job satisfaction}

Thirdly, the topic of power came into play across the qualitative findings on JS. Here, several managers criticised the use and the misuse of power in the organisation, noting that this had a negative impact on their JS:

- Seven managers emphasised that power was used in different ways in the organisation, affecting the JS of employees (P3, P7, P8, P10, P12, P13, P14). These seven managers felt that power was used to influence people and processes (P3, P7, P8, P10, P12, P13, P14).

- Six managers felt that power was generally misused in the organisation (P1, P2, P3, P11, P12, P15).
- Four interviewees felt that power was particularly misused regarding the 'levels of authorities' (P6, P15, $\mathrm{P} 16, \mathrm{P} 17)$, thereby referring to individuals in higher hierarchical positions.

- Three interviewees saw power being used through team approach and participation (P1, P7, P17), referring, for example, to individuals who used the team for their personal and individual purposes.

- Three managers felt that power was used in a destructive way (P11, P12, P13).

- Two managers stressed that power was used for own individual benefit (P8, P10).

- Two managers emphasised that power was used to 'motivate people' (P3, P7).

- Two managers pointed out that power was used to 'make decisions' (P13, P14) by dominating the decision-making processes.

- One person pointed out that power was misused due to the lack of female power (P1). This person felt that a balance in terms of numbers of male and female top managers would lead to a more balanced use of power within the organisation and women leaders would contribute to a healthy use of power within the organsaition.

Managers in the organisation had a rather negative understanding of the way in which power was used on an individual and organisational basis. They felt that positive behaviour associated with constructive power use was missing. The managers had the impression that power was misused. However, they also mentioned strategies for dealing with the misuse of power.

Interviewee P1 explored how the misuse of power affected JS, although the interviewee felt it was normal for a business:

'We do see abuses of power. It's normal for a business. We saw it at the top with [...]. Some of us feel he abused his position. I think at our level we generally don't; we work very well together, so we're not creating silo effects between the different sections. As a team we work very well together and we've achieved very well together.' (P1).

In spite of the negative aspect of misuse of power, this top manager emphasised that at his level of management colleagues usually worked well together, decreasing silo effects between the different sections and still achieving their goals.

Interviewees stressed that power was particularly misused at certain levels of authority (P6, P15, P16, P17). Not only was power seen as negative and misused, but a few interviewees also highlighted the positive aspects of power (motivate people, make decisions). However, power is used to influence people and processes and therefore creates dissatisfaction for managers in this specific organisation. One manager was of the opinion that women in power could help to shift the use of power in a more positive direction. According to this statement, a higher percentage of female leaders in the organisation could affect the JS in general. 


\section{Qualitative findings on organisational commitment}

Qualitative findings on OC were as follows:

- Eight managers felt committed to the organisation (P3, P4, P6, P7, P10, P11, P14, P17).

- Four managers felt committed owing to positive collegial relationships with colleagues (P7, P9, P11, P14).

- Three managers were committed as a result of their positive influence on the environment and on others (P3, P5, P6).

- Two managers felt committed because of the enabling work environment (P1, P9).

- Three managers were committed because of the location of the organisation in the Eastern Cape (P2, P9, P16).

- Eight of the 17 managers stated explicitly that the financial aspects of the job did not make them feel committed (P3, P4, P6, P7, P10, P11, P14, P17). The aspect of financial security did not have an impact on the managers' OC (P3).

Four interviewees felt particularly committed to the organisation because of the colleagues working with them. P11 stated that she enjoyed working with colleagues who made her feel committed. She was also delighted by the fact that she was contributing to an important societal issue by working in the organisation, which showed her high affective commitment:

'I value my colleagues very much and I would really lose friends and colleagues if I left the organisation. I also feel committed with regard to my colleagues to stay here. I would really lose good collegial relationships. And we are working together towards an important issue of society.' (P11)

Another manager (P3) maintained that the OC was strongly influenced by the positive relationships with colleagues, as well as by the high social impact of the organisation on society. The affective commitment was emphasised:

'I do a good job because working for the organisation I know that I am doing something important for the organisation, but also for the community, for the province and for the state. I am dealing with a very important issue for society and human beings.' (P3)

This statement shows that commitment was understood not only as OC, but also to the community and society. The interpersonal and micro-psychological dimension, as well as the social dimension in terms of colleagues, the community and the society were relevant to managers in terms of OC.

\section{Discussion}

Both the quantitative and qualitative findings on JS indicate that the managers were satisfied with their co-workers, with work and with their relationships with supervisors. A feeling of satisfaction towards motivational strategies was also evident. The qualitative findings show that the public utility had a positive work environment and employees were generally satisfied with supervisors. However, three areas of concern were raised during the interviews, namely pay, promotion and the use of power. The relevant closeness of the pay and promotion mean scores indicated that respondents viewed these two scales of JS as relatively similar. There was also a general feeling that the selected public utility was an organisation in which it was difficult to be promoted. Gaining power and an increase in pay seemed to be difficult from the perspective of the employees. Despite this, the overall JS at this organisation contributed to $\mathrm{POB}$ (Youssef \& Luthans 2007).

In terms of concern over pay, research in South Africa has found that (Lumley et al. 2011):

In order to create a working environment that encourages people to stay with their respective organisations, managers need to review existing pay practices so as to offer fair pay, provide challenging and meaningful work tasks, and foster positive co-worker relationships. (p. 115)

The significant differences in the average scores between Co-Workers and Pay, Co-Workers and Promotion, Pay and Supervision, Pay and Work, Promotion and Supervision, and Promotion and Work imply that if the organisation wanted to attract staff and foster employee JS, then they would need to promote a positive work environment, which would include the good relationships with supervisors and co-workers. However, the organisation would have to pay attention to reducing the negative perceptions about pay and promotion, relative to the work environment. Since no significant linear relationships were found between the scales on the JDI, it is clear that JS scales did not influence each other in a linear manner.

Overall, the findings on OC indicate that affective commitment scored significantly higher than continuance and normative commitment, which implies that the individual is considered to have 'an affective or emotional attachment to the organisation such that the strongly committed individual identifies with, is involved in, and enjoys membership in the organisation' (Allen \& Meyer 1990:16). According to Wasti (2003:304), affective commitment has the strongest and most consistent difference with advantageous outcomes for the organisation, and this has been very well researched. This is confirmed by the meta-analyses conducted by Mathieu and Zajac (1990), who suggest that the majority of research indicates that affective commitment can be expected to have the strongest positive impact upon desirable employee behaviours and, according to Chen et al. (2007:1130), on job performance. OC at the same time provides employees with stability and feelings of belonging and thereby contributes to reduced stress and increased health and well-being in organisations (Mathieu \& Zajac 1990; Siu 2002). Continuance commitment was considered an important factor only in terms of the preferred location of the organisation in the Eastern Cape. A significant linear relationship was found between affective and normative commitment, implying that there was a correlation between an emotional attachment to the organisation and feeling obliged to continue working for it. 
With regard to JS and OC, a significant linear relationship was found between supervision and affective commitment. This finding is confirmed by Kotze and Roodt (2005) and Lumley et al. (2011), who have found strong positive relationships between JS and OC. It is interesting that Spector's (2008) study indicates similar results to this study, in that JS relates most strongly to affective commitment. Moreover, the meta-analysis conducted by Mathieu and Zajac (1990:183) accepted the hypothesis that 'attitudinal commitment' would be related more strongly to overall JS and satisfaction with supervision, which further validates the findings of this study.

\section{Conclusion and implications}

JS and OC support $\mathrm{POB}$ in the organisation. JS in the organisation is supported by collegial relationships and collegial support. Managers are critical of the way in which power is used in an organisation. Although most of the findings show positive perspectives on JS and OC, the qualitative findings on power emphasise that there are underlying issues in the organisation that need to be focused on in the future.

According to the quantitative data, managers seem to be dissatisfied with pay and promotion. However, this dissatisfaction is hardly displayed in the qualitative data. This might be due to the fact that the interviewees are hesitant to mention their concerns openly in a face-to-face interview.

Affective and continuous commitment are deemed to be more important than normative commitment. Based on the qualitative findings, affective commitment is more emphasised by highlighting positive collegial relationships and the positive influence of the work on society, as well as the enabling work environment. Continuous commitment is only mentioned in terms of the importance of the location of the organisation in the Eastern Cape.

The significant linear relationship between affective commitment and supervision implies that those who supervise or manage others have an important effect on the level of emotional commitment to the organisation. Since the potential misuse of power was highlighted as a concern, it is important that supervisors do not misuse power in such a way that the affective commitment of the managers will be negatively influenced.

On a practical level, managers should increase their awareness in leadership and management training towards positive work and life concepts in terms of POB. This POB perspective in organisations also opens new perspectives whilst creating a positive and future-orientated mindset, which may spill over into society and other organisations. In terms of JS, managers in an organisation should act as role models and speak openly about their perceptions of JS, thereby reinforcing the positive aspects of the job. Although the OC is high, the organisation should strive to have a workforce with a high level of affective commitment by aligning organisational and employee values and goals through consulting, development and training programmes. The organisation should pay attention to the ways power is used by individual employees, and train employees on how to deal with power, decision-making and interpersonal and inter-hierarchical communication, in order to turn negative perceptions of power use into positive new ways of dealing with power.

\section{Acknowledgements}

We thank the participants and the organisation for participating in this research project.

\section{Competing interests}

The authors declare that they have no financial or personal relationship(s) that may have inappropriately influenced them in writing this article.

\section{Authors' contributions}

L.L. (Department of Management, Rhodes University) contributed towards theory development, gathered quantitative data, responsible for reporting on quantitive findings, implications and conclusion, as well as overall editing.C.M. (Department of Management, Rhodes University) was responsible for theory development, gathered qualitative data, responsible for reporting on qualitative findings, implications and conclusion. J.B. (Department of Statistics, Rhodes University) was responsible for quantitative data analysis and contributed towards the discussion and implications.

\section{References}

Aamodt, M.G., 2007, Industrial/organisational psychology: An applied approach Wadsworth Cengage Learning, Belmont, CA.

Alessandri, G., Veccione, M., Tisak, J., Deiana, G., Caria, S. \& Caprara, G.V., 2012, 'The utility of positive orientation in predicting job performance and organisational citizenship behaviours', Applied Psychology: An International Review 61(4), 669-698. http://dx.doi.org/10.1111/j.1464-0597.2012.00511.x

Allen, N.J. \& Meyer, J.P., 1990, 'The measurement and antecedents of affective, continuance and normative commitment to the organization', Journal of Occupational Psychology (63), 1-18. http://dx.doi.org/10.1111/j.2044-8325.1990. tb00506.x

Beck, N. \& Wilson, J., 2000, 'Development of affective organisational commitment: A cross-sequental examination of change with tenure', Journal of Vocational Behaviour 56(1), 114-136. http://dx.doi.org/10.1006/jvbe.1999.1712

Becker, H.S., 1960, 'Notes on the concept of commitment', American Journal of Sociology 66(1), 32-40. http://dx.doi.org/10.1086/222820

Begley, T.M. \& Czajka, J.M., 1993, 'Panel analysis of the moderating effects of commitment on job satisfaction, intent to quit, and health following organisational change', Journal of Applied Psychology 78(4), 552-556. http:// dx.doi.org/10.1037/0021-9010.78.4.552

Berger, P.L., \& Luckmann, T., 2000, Die gesellschaftliche Konstruktion der Wirklichkeit. Eine Theorie der Wissenssoziologie, 17th edn., Fischer, Frankfurt.

Brief, A., 2003, 'Editor's comments: AMR - The often misunderstood journal', Academy of Management Review 28(1), 7-8. http://dx.doi.org/10.5465/ AMR.2003.26042683

Buitendach, J.H. \& De Witte, H., 2005, 'Job insecurity, extrinsic and intrinsic job satisfaction and intrinsic organisational commitment of maintenance workers in a public utility', South African Journal of Business Management 36(2), 27-38.

Chen, S.-J., Lin, P.-F., Lu, C.-M. \& Tsao, C.-W., 2007, 'The moderation effect of $H R$ strength on the relationship between employee commitment and job performance', Social Behavior and Personality 35(8), 1121-1138. http://dx.doi. org/10.2224/sbp.2007.35.8.1121

Clugston, M., Howell, J.P. \& Dorfman, P.W., 2000, 'Does cultural socialization predict multiple bases and foci of commitment?', Journal of Management 26(1), 5-30. http://dx.doi.org/10.1016/S0149-2063(99)00034-3 
Coetzee, S.E., \& Rothmann, S., 2005, 'Occupational stress, organisational commitment, ill-health of employees at a higher educational institution in South Africa', Journal of Industrial Psychology 31(1), 47-54.

Collis, J. \& Hussey, R., 2003, Business research: A practical guide for undergraduate and postgraduate students, 2nd edn., Palgrave Macmillian, New York.

Colquitt, J.A. \& Zapata-Phelan, C.P., 2007, 'Trends in theory building and theory testing: A five-decade study of the Academy of Management Journal', Academy of Management Journal 50(6), 1281-1303. http://dx.doi.org/10.5465/ AMJ.2007.28165855

Corley, K.G. \& Gioia, D.A., 2011, 'Building theory about theory building: What constitutes a theoretical contribution?', Academy of Management Review 36(1) 12-32. http://dx.doi.org/10.5465/AMR.2011.55662499

Creswell, J.W. \& Plano Clark, V.L., 2007, Designing and conducting mixed methods research, Sage, Thousand Oaks, CA.

Du Plessis, Y. \& Barkhuizen, E.N., 2011, 'Strategic role of human resource professionals in a South African context', paper presented at the 15th European Association of Work and Organisational Psychology Conference, Maastricht, The Netherlands, of Work and 28 May.

Du Plessis, Y. \& Barkhuizen, N., 2012, 'Psychological capital, a requisite for organisational performance in South Africa', South African Journal of Economic arganisational performance in South Africa

Edoho, F.M., 2001, Management challenges for Africa in the twenty-first century. Theoretical and applied perspectives, Praeger, Westport.

Fashoyin, T., 2005, 'Management in Africa', Lagos Organisation Review 1(1), 43-45.

Fisher, C.D., 1998, 'Mood and emotions while working - Missing pieces of job satisfaction. School of Business Discussion Papers. Paper 64. Queensland: Bond University', viewed 26 June 2014, from http://epublications.bond.edu.au/ discussion_papers/64.

Gbadamosi, G., 2003, 'HRM and the commitment rhetoric: Challenges for Africa', Management Decision 41(3), 274-280. http://dx.doi. org/10.1108/00251740310475218

Geertz, C., 1987, La interpretación de las culturas, Gedisa, Barcelona.

Gruneberg, M.M., 1979, Understanding job-satisfaction, McMillan, London.

Hair, J.F., Money, A.H., Samouel, P. \& Page, M., 2007, Research methods for business, Wiley, West Sussex, UK.

Harrison, D.A., Newman, D.A. \& Roth, P.L., 2006, 'How important are job attitudes? Meta-analytic comparisons of integrative behavioural outcomes and time sequences', Academy of Management Journal 49(2), 305-325. http://dx.doi. org/10.5465/AMJ.2006.20786077

Houghton, J.D. \& Jinkerson, D.L., 2007, 'Constructive thought strategies and job satisfaction: A preliminary examination', Journal of Business and Psychology 22(1) 45-53. http://dx.doi.org/10.1007/s10869-007-9046-9

Huang, T.C. \& Hsiao, W.-J., 2007, 'The causal relationship between job satisfaction and organisational commitment', Social Behaviour and Personality 35(9), 1265-1276. http://dx.doi.org/10.2224/sbp.2007.35.9.1265

Illies, R., Scott, B.A. \& Judge, T.A., 2006, 'The interactive effects of personal traits and experienced states on intraindividual patterns of citizenship' Academy of Management Journal 49(3), 561-575. http://dx.doi.org/10.5465/ AMJ.2006.21794672

Inyang, B.J., 2008, 'The challenges of evolving and developing management indigenous theories and practices in Africa', International Journal of Business and Management 3(12), 122-132.

Jackson, T., 2002, 'Reframing human resource management in Africa: A cross-cultural perspective', The International Journal of Human Resource Management 13(7), 998-1018. http://dx.doi.org/10.1080/09585190210131267

Jackson, T., 2004, Management and change in Africa, Routledge, London. http:// dx.doi.org/10.4324/9780203477069

Jackson, T., Louw, L. \& Zhao, S., 2013, 'China in Sub-Saharan Africa: Implications for HRM policy and practice at organizational level', The International Journal of Human Resource Management 24(13), 2512-2533. http://dx.doi.org/10.1080/0 9585192.2012.725067

Jacob, N., 2005, 'Cross-cultural investigations: Emerging concepts', Journal of Organizational Change Management 18(5), 514-528. http://dx.doi. org/10.1108/09534810510614986

Judge, T.A., Higgins, C.A., Thoresen, C. \& Barrick, M.R., 1999, 'The big five personality traits, general mental ability, and career success across the life span', Personnel traits, general mental ability, and career success across the life span', Personnel
Psychology 52(3), 621-652. http://dx.doi.org/10.1111/j.1744-6570.1999. Psychology
tb00174.x

Jung, C.S. \& Ritz, A., 2014, 'Goal management, management reform, and affective organizational commitment in the public sector', International Public Management Journal 17(4), 463-492. http://dx.doi.org/10.1080/10967494.2014.958801

Kamoche, K., 2011a, 'Contemporary developments in the management of human resources in Africa', Journal of World Business 46(1), 1-4. http://dx.doi. org/10.1016/j.jwb.2010.05.011

Kamoche, K., 2011b, 'Introduction: Human resource management in Africa', The International Journal of Human Resource Management 13(7), 993-997. http:// dx.doi.org/10.1080/09585190210131258

Kanter, R.M., 1968, 'Commitment and social organisation: A study of commitment mechanisms in Utopian communities', American Sociological Review 33(4), 499517. http://dx.doi.org/10.2307/2092438

Kantor, J., 1991, 'The effects of computer administration and identification on the Job Descriptive Index (JDI)', Journal of Business and Psychology 5(3), 309-323. http:// dx.doi.org/10.1007/BF01017705
Kass, S.J., Vodanovich, S.J. \& Callender, A., 2001, 'State-trait boredom: Relationship to absenteeism, tenure and job satisfaction', Journal of Business and Psychology 16(2), 317-327. http://dx.doi.org/10.1023/A:1011121503118

Kiggundu, M.N., 1991, 'The challenges of management development in sub-Saharan Africa', Journal of Management Development 10(6), 32-47. http://dx.doi. org/10.1108/02621719110004411

Kilduff, M., 2006, 'Editor's comments: Publishing theory', Academy of Management Review 31(2), 252-255. http://dx.doi.org/10.5465/AMR.2006.20208678

Kinicki, A.J., McKeee-Ryan, F.M., Schriesheim, C.A. \& Carson, P.K., 2002, 'Assessing the construct validity of the Job Descriptive Index: A review and meta-analysis', Journal of Applied Psychology 87(1), 14-32. http://dx.doi.org/10.1037/0021 9010.87.1.14

Kotze, K. \& Roodt, G., 2005, 'Factors that affect the retention of managerial and specialist staff: An exploratory study of an employee commitment model', South African Journal of Human Resource Management 3(2), 48-55. http://dx.doi. org/10.4102/sajhrm.v3i2.65

Krüger, J. \& Rootman, C., 2010, 'How do small business managers influence employee satisfaction and commitment?', Acta Commercii 10(2), 59-72.

Lee, K., Allen, N.J., Meyer, J.P. \& Rhee K-Y., 2001, 'The three-component model of organisational commitment: An application to South Korea', Applied Psychology: An organisational commitment: An application to South Korea', Applied Psychology: An
International Review 50(4), 596-614. http://dx.doi.org/10.1111/1464-0597.00075

Lok, P. \& Crawford, J., 2004, 'The effect of organisational culture and leadership style on job satisfaction and organisational commitment', Journal of Management Development 23(4), 321-338. http://dx.doi.org/10.1108/02621710410529785

Louw, L., Mayer, C.-H. \& Baxter, J., 2012, 'Exploring the relationship between valueand life-orientation and job satisfaction', Acta Commercii 12, 45-67.

Louw, M.J. \& Boshoff, C., 2006, 'Cacadu organisational culture survey: 2005', unpublished report for Harvard Management Consultants CC, Cacadu District Municipality, Port Elizabeth.

Lumley, E.J., Coetzee, R., Tladinyane, R. \& Ferreira, N., 2011, 'Exploring the job satisfaction and organisational commitment of employees in the information technology environment', Southern African Business Review 15(1), 100-118.

Luthans, F., 2002a, 'The need for and meaning of positive organisation behavior', Journal of Organisational Behavior 23, 695-706. http://dx.doi.org/10.1002/job.165

Luthans, F., 2002b, 'Positive organisational behavior: Developing and managing psychological strengths', Academy of Management Executive 16, 57-72. http:// dx.doi.org/10.5465/AME.2002.6640181

Luthans, F., Youssef, C.M. \& Avolio, B.J., 2007, Psychological capital, Oxford University Press, New York.

Lyubomirsky, S., 2013, The myth of happiness: What should make you happy but doesn't, what shouldn't make you happy but does, what happiness really is - and isn't, Penguin, New York.

Manetje, O.M., 2005, 'Impact of organisational culture on organisational commitment', unpublished thesis for Master of Arts, University of South Africa, Pretoria.

Mangaliso, M.P., 2001, 'Building competitive advantage from Ubuntu: Management lessons from South Africa', Academy of Management Perspectives 15(3), 23-33.

Mathieu, J.E. \& Zajac, D.M., 1990, 'A review and meta-analysis of the antecedents, correlates, and consequences of organizational commitment', Psychological Bulletin 108(2), 171-194. http://dx.doi.org/10.1037/0033-2909.108.2.171

Mayer, C.-H., 2008, Managing conflict across cultures, values and identities, Waxmann, Münster.

Mayer, C.-H., 2011, The meaning of sense of coherence in transcultural management Waxmann, Münster.

Mayer, C.-H., Louw, L. \& Louw, T., 2010, 'Sense of Coherence and Organisational Commitment: A case study in a selected South African parastatal', competitive paper presented at the 22 nd Annual Conference of the Southern Africa Institute for Management Scientists (SAIMS), Port Alfred, South Africa, 12-15 September.

Mayer, C.-H., \& Van Zyl, L.E., 2013, 'Perspectives of female leaders on sense of coherence and mental health in an engineering environment', SA Journal of Industrial Psychology 39(2), viewed 29 March 2014, from http://dx.doi. org/10.4102/ sajip.v39i2.1097.

Meyer, J.P. \& Allen, N.J., 1991, 'A three-component conceptualisation of organisational commitment', Human Resource Management Review 1(1), 61-89. http://dx.doi. org/10.1016/1053-4822(91)90011-Z

Meyer, J.P., Stanley, D.J., Herscovitch, L. \& Topolnytsky, L., 2002, 'Affective, continuance, and normative commitment to the organization: A meta-analysis of antecedents, correlates, and consequences', Journal of Vocational Behavior 61(1), 20-52. http://dx.doi.org/10.1006/jvbe.2001.1842

Mowday, R.T., Steers, R.M. \& Porter, L.W., 1979, 'The measurement of organisational commitment', Journal of Vocational Behaviour 14(2), 224-247. http://dx.doi. org/10.1016/0001-8791(79)90072-1

Nunnally, J., 1978, Psychometric theory, 2nd edn., McGraw-Hill, New York.

Nyengane, M.H., 2007, 'The relationship between leadership style and employee commitment: An exploratory study in an electricity utility of South Africa', unpublished thesis for Master of Business Administration, Rhodes University, Grahamstown.

Pennington, M.C. \& Riley, P.V., 1991, 'Measuring job satisfaction in ESL using the Job Descriptive Index. Perspectives', Working papers of the Department of English, City Polytechnic of Hong Kong 3(1), 20-36.

Pillay, K., 2008, 'Sense of coherence, work engagement and organisational commitment within an automotive development institute', Master thesis, Dept. of Industrial and Organisational Psychology, University of South Africa, viewed of Industrial and Organisational Psychology, University of South Africa, viewed
3 March 2013, from http://uir.unisa.ac.za/dspace/bitstream/10500/3168/1/ dissertation_pillay_k.pdf. 
Pittorini, L.A. 2008, 'The relationship between culture, commitment and performance in a South African electricity utility', unpublished Master thesis, Rhodes University, Grahamstown.

Poggenpoel, M., 1998, 'Data analysis in qualitative research', in A.S. de Vos (ed.), Research on grass roots: A primer for the caring professions, pp. 334-353, Van Schaik, Pretoria.

R Development Core Team, 2010, R: A language and environment for statistical computing. R Foundation for Statistical Computing, viewed 26 June 2014, from http://www.R-project.org/

Rahman, M. \& Iqbal, F., 2013, 'A comprehensive relationship between job satisfaction and turnover intention of private commercial bank employees' in Bangladesh', International Journal of Science and Research 2(6), 17-23.

Rashid, Z.A., Sambasivan, M., \& Johari, J., 2003, 'The influence of corporate culture and organisational commitment on performance', Journal of Management Development 22(8), 708-728. http://dx.doi.org/10.1108/02621710310487873

Rayton, B.A. \& Yalabik, Z.Y., 2014, 'Work engagement, psychological contract breach and job satisfaction', International Journal of Human Resource Management 25(17), 2382-2400. http://dx.doi.org/10.1080/09585192.2013.876440

Riege, M.A., 2003, 'Validity and reliability tests in case study research: A literature review with "hands-on" applications for each research phase', Qualitative Market Research: An International Journal 6(2), 75-86. http://dx.doi. Market Research: An Internation
org/10.1108/13522750310470055

Riggio, R.E., 2009, Introduction to Industrial/Organisational Psychology, Pearson, London.

Roberts, L.M., 2006, 'Shifting the lens on organisational life: The added value of positive scholarship', Academy of Management Review 31(2), 292-305. http:// dx.doi.org/10.5465/AMR.2006.20208681

Robinson, J.P., Shaver, P.R. \& Wrightsman, L.S., 1991, 'Criteria for scale selection and evaluation', in J.P. Robinson, P.R. Shaver \& L.S. Wrightsman (eds.), Measures of personality and social psychological attitudes, pp. 1-16, Academic Press, San Diego. http://dx.doi.org/10.1016/B978-0-12-590241-0.50005-8

Salkind, N.J. (ed.), 2010, Encyclopedia of research design, vol. 1, Sage, London, pp. 1-1776. http://dx.doi.org/10.4135/9781412961288

Seale, C., 2002, 'Quality issues in qualitative inquire', Qualitative Social Work 1(1) 97-110. http://dx.doi.org/10.1177/147332500200100107

Sekaran, U., 1992, Research methods for business: A skill building approach, 2nd edn., John Wiley \& Sons, New York.

Sempane, M.E., Rieger, H.S. \& Roodt, G., 2002, 'Job satisfaction in relation to organisational culture', South African Journal of Industrial Psychology 28(2), viewed 26 June 2014, from http://www.sajip.co.za/index.php/sajip/article/ view/49.

Siu, O.L., 2002, 'Occupational stressors and well-being among Chinese employees: The role of organisational commitment', Applied Psychology: An International Review 5, 527-544. http://dx.doi.org/10.1111/1464-0597.t01-1-00106
Smith, P.C., Kendall, L.M. \& Hulin, C.L., 1969, The measurement of satisfaction in work andretirement: A strategy for the study of attitudes, Rand McNally, Chicago.

Spector, P., 2008, Industrial and organisational behaviour, 5th edn., John Wiley \& Sons, New Jersey.

Strümpfer, D.J.W. \& De Bruin, G.P., 2009, 'Antonovsky's sense of coherence and job satisfaction: Meta-analyses of South African data', SA Journal of Industrial Psychology 35(1), 87-96.

Tashakkori, A. \& Teddlie, C., 1998, Mixed methodology: Combining qualittive and quantitative approaches. Applied Social Research Methods Series, vol. 46, Thousand Oaks / Sage, London.

Terre Blanche, M., Durrheim, K. \& Kelly, K., 2006, 'First steps in qualitative data analysis', in M. Terre Blanche, K. Durrheim \& D. Painter (eds.), Research in practice: Applied methods for the social sciences, pp. 321-344, University of Cape Town, Cape Town.

Van der Merwe, A., 2005, Health and happiness, HSM, Cape Town.

Van der Riet, M. \& Durrheim, K., 2008, 'Putting design into practice: Writing and evaluating research proposals', in M. Terre Blanche, K. Durrheim \& D. Painter (eds.), Research in practice: Applied methods for the social sciences, pp. 80-112, University of Cape Town, Cape Town.

Van Dyk, J. \& Coetzee, M., 2012, 'Retention factors in relation to organisationa commitment in medical and information technology services', SA Journal of Human Resource Management 10(2), 1-11. http://dx.doi.org/10.4102/sajhrm.v10i2.433

Van Stuyvesant-Meijen, J., 2007, 'The influence of organisational culture on organisational commitment at a selected local municipality', unpublished Master's thesis, Rhodes University, Grahamstown.

Van Zyl, L.E. \& Stander, M.W., 2013, 'The strengths based coaching model', in J. White, R. Motching \& M. Lux (eds.), Theory and practice of the person-centered approach Interconnections beyond psychotherapy, pp. 132-149, Springer, New York.

Walumbwa, F., Orwa, B., Wang, P. \& Lawler, J.J., 2005, 'Transformational leadership, organisational commitment, and job satisfaction: A comparative study of Kenyan and U.S. financial firms', Human Resource Development Quarterly 16(2), 235-256. http://dx.doi.org/10.1002/hrdq.1135

Wasti, S.A., 2003, 'Organisational commitment, turnover intentions and the influence of cultural values', Journal of Occupational \& Organisational Psychology 76(3), 303-321. http://dx.doi.org/10.1348/096317903769647193

Wright, T.A. \& Bonett, D.G., 2002, 'The moderating effects of employee tenure on the relation between organisational commitment and job performance: A meta-analysis', Journal of Applied Psychology 87(6), 1183-1190. http://dx.doi. org/10.1037/0021-9010.87.6.1183

Youssef, C.M. \& Luthans, F., 2007, 'Positive organisational behaviour in the workplace: The impact of hope, optimism, and resilience', Journal of Management 33(5), 774-800. http://dx.doi.org/10.1177/0149206307305562

Zoogah, D.B., 2008, 'African business research: A review of studies published in the Journal of African Business and a framework for enhancing future studies', Journal of African Business 9(1), 219-255. http://dx.doi.org/10.1080/15228910802053037 